\title{
KEMAMPUAN MENYUSUN KEMBALI ISI PANTUN ANAK DENGAN MENGGUNAKAN TEKNIK SKRAMBEL SISWA KELAS IV SDN 4 TELAGA JAYA KABUPATEN GORONTALO
}

\author{
Hendra Saputra S Adiko \\ Staf Dosen Fakultas IImu Pendidikan \\ Universitas Muhammadiyah Gorontalo \\ Email : hendra.adikoumg@gmail.com
}

\begin{abstract}
This studi aims to determin the real situation and to identify factors inhibiting the effektiviness of public services in integrated licensing services office, in this study, the dependent variabels and integrated licensing services office, in this study. The methods used are: deskriktif methods, such ase the deployment questionnaire, and an interview in the related parties whereas this study, the dependent variables and independent variabels. The background of this study, service is the essentials of the figure of the figure of the apparatus, as civil servants and publuc servant. This task has been clearly outlined in the preambele of the 1945 constution alenia foure, which includes four (4) aspects of the apparatus, esenstials services to the community, which is to protect all the people of indonesia and the entire country of indonesia, promote the general welfare,the intellectual life of the nation and the establishment of world order based on freedom,eternal peace and social justice. The results and conclusions that integrated care licensing office is very effective in providing licensing services to the community for appropriate time specified,although it is still under the process and the steps that have been set,as well as the corresponding system service running today,saranya that needs to be good cooperation, between employees and management,and the whole team there.
\end{abstract}

Keywords: Effectiveness, Public, Service

\begin{abstract}
Abstrak
Dalam kegiatan menyusun isi pantun anak selalu dipandang hanya dilakukan oleh orang-orang yang memiliki bakat, sulitnya menuangkan ide atau gagasan dalam pikiran mereka. Sehingga pembelajaran menyusun isi pantun anak dianggap sulit bagi siswa. Metode penelitian adalah Penelitian Tindakan Kelas dengan menggunakan teknik pengumpulan data: observasi, Tes, dan Dokumnetasi dan subjek dalam penelitian ini adalah 22 orang siswa kelas IV SDN 4 Telaga Jaya Kab. Gorontalo. Hasil kemampuan siswa dalam menyususn kembali isi pantun anak melalui teknik skrambel dapat ditingkatkan, yang ditunjukan dengan indikator kinerja Untuk kemampuan siswa dalam menyusun isi pantun anak minimal $75 \%$ dari 22 orang jumlah seluruh siswa yang dikenai tindakan. Hal ini di tunjukan oleh hasil capain siswa rata-rata memperoleh nilai minimal Kesimpulan berdasarkan hasil penelitian tindakan kelas yang dilaksanakan selama dua siklus dapat di simpulan bahwa dengan menggunakan teknik skrambel pada siswa kelas IV SDN 4 Telaga Jaya Kab. Gorontalo. hasil kemampuan siswa dalam menyusun kembali isi pantun anak meningkat.
\end{abstract}

Kata Kunci : Kemampuan,Pantun, Teknik Skrambel 


\section{PENDAHULUAN}

Sastra merupakan peristiwa atau hal-hal penting yang pernah dilihat, dihayati, dipikirkan, dan dirasakan oleh pengarangnya dalam kehidupan sehari-hari. Secara singkat dan sederhana dapatlah dikatakan bahwa sastra adalah pembayangan atau pelukisan kehidupan dan pikiran imajinatif ke dalam bahasa baik berupa tulisan maupun lisan.

Pada dasarnya sastra dibagi menjadi dua. Pertama sastra imajinatif dan yang kedua sastra non imajinatif. Sastra imajinatif adalah karya sastra yang berasal dari daya khayal atau imajinasi pengarang. Dan sangat tipis hubunganya dengan fakta dan realita kehidupan. Yang termasuk dalam sastra imajinatif adalah puisi dan prosa. Salah satu karya sastra imajinatif yang terdapat di dalam kurikulum dan dipelajari di sekolah dasar adalah puisi lama yaitu pantun.

Dalam kegiatan menyusun isi pantun anak selalu dipandang hanya dilakukan oleh orang-orang yang memiliki bakat, sulitnya menuangkan ide atau gagasan dalam pikiran mereka. Sehingga pembelajaran menyusun isi pantun anak dianggap sulit bagi siswa, karena pandangan bahwa menulis pantun diperlukan suatu kreativitas, imajinasi yang tinggi, adanya kesulitan siswa dalam menyusun kalimat dalam baris pantun, baik berupa sampiran maupun isi yang sesuai dengan tema serta menyusuaikan rima antara sampiran dan isi. Mereka mengganggap bahwa dalam menyusun pantun hanya dilakukan oleh pecinta sastra saja. Dimana menurut Panghulu (2008:2) teorinya bahwa pantun atau puisi lama terikat dengan beberapa aturan, di antaranya: jumlah kata dalam satu baris, jumlah baris dalam satu bait, persajakan (rima), dan banyaknya suku kata tiap baris. Demikian pula pengajaran yang kurang bisa menerapkan metode, strategi maupun teknik pembelajaran yang kurang tepat, sehingga terasa menjenuhkan.

Kenyataan yang terjadi pada siswa kelas IV SDN 4 Telaga Jaya Kab. Gorontalo dalam Pembelajaran bahasa Indonesia khususnya dalam menyusun isi pantun di kelas dengan teknik ceramah yang dipariasikan dengan metode pemberian tugas terasa suatu pekerjaan yang menjenuhkan bagi siswa, Saat ini siswa lebih suka bermain dan santai dari pada mendengarkan ceramah guru, dan pada akhir pembelajaran siswa mengerjakan tugas yang diberikan oleh guru. Akibatnya kemampuan siswa tidak seperti yang diharapkan oleh kriteria ketuntasan minimal (KKM) yang telah ditetapkan oleh sekolah.

Dari hasil pemantauan pada observasi awal yang dilakukan di kelas ketika diberi pelajaran bahasa Indonesia khususnya dalam menyusun isi pantun anak terlihat $60 \%$ siswa tidak tertarik, acuh tak acuh, beberapa siswa selalu bercakap-cakap dengan teman sebangkunya, sebagian besar siswa tidak memperhatikan penjelasan guru, dan ketika diajukan pertanyaan, semua siswa diam, sibuk membaca kembali pantun, jawaban siswa tidak mencapai sasaran. Dengan suasana proses pembelajaran seperti ini secara otomatis berdampak pada rendahnya hasil capaian siswa dimana dari 22 orang jumlah keseluruhan siswa yang telah tuntas hanya terdapat 5 orang siswa atau jika dipersentasekan hanya $23 \%$. Sedangkan siswa yang belum tuntas masih mendominasi dengan 17 orang siswa atau $77 \%$. Ketidak mampuan siswa menyusun pantun disebabkan oleh: 1) siswa mengalami kesulitan dalam menyusun kata dalam baris pantun; 2) siswa masih sulit menyusun sampiran dan isi pantun; 3) teknik pembelajaran yang digunakan oleh guru masih monoton dengan ceremah.

Dari hasil capain siswa tersebut, dapat disimpulkan bahwa teknik ceramah tidak cocok digunakan untuk menanamkan konsep menyusun pantun anak sehingganya guru ditantang untuk menggali kreativitas dalam mengembangkan teknik pembelajaran untuk meningkatkan kemampuan menyusun isi pantun anak agar imajinasi dan pemahaman siswa akan terangsang. Melihat karakteristik anak SD khususnya anak SD masih cenderung dengan bermain, maka gurupun dalam penyampaian materi haruslah memilih teknik pembelajaran yang sesuai dengan karakteristik anak berupa teknik skrambel. Teknik skrambel biasanya dipakai oleh anak-anak sebagai permainan yang pada dasarnya merupakan latihan pengembangan dan peningkatan wawasan pemilikan kosakata-kosakata dan huruf-huruf yang tersedia.

Berdasarkan uraian di atas maka solusi dalam meningkatkan kemampuan menyusun pantun anak tersebut yakni dengan Teknik skrambel, dimana teknik pembelajaran dalam menyusun pantun berkaitan erat dengan latihan mempertajam penalaran, dan daya khayal, serta kepekaan terhadap imijinasi siswa. 
Sasaran utamanya sama, yakni mengajak anak untuk berlatih menyusun pantun anak agar menjadi lebih bermakna.

Melalui teknik skrambel ini disamping anak berlatih memprediksi jalan pikiran penulisan aslinya, juga mengajak anak untuk lebih berkreasi dengan susunan baru yang mungkin lebih baik dari susunan semula. Teknik pembelajaran skrambel merupakan salah satu teknik pembelajaran yang menyenangkan karena selain menekankan pada penguasaan materi di dalamnya juga ada unsur permainan. Sehingga proses kegiatan pembelajaran menjadi menyenangkan dan siswa tidak bosan untuk belajar.

Berdasarkan uraian tersebut di atas, maka penulis sangat tertarik untuk mengangkat dan mengadakan penelitian bagaimana meningkatkan Kemampuan siswa menyusun kembali isi pantun anak dengan menggunakan teknik skrambel pada siswa kelas IV SDN 4 Telaga Jaya Kabupaten Gorontalo.

\section{METODE PENELITIAN}

Penelitian ini dilaksanakan di SDN 4 Telaga Jaya Kabupate Gorontalo yang berlokasi di kecamatan Telaga Jaya. Sekolah ini merupakan sekolah inti di gugus IV Kecamatan Telaga Jaya. Waktu pelaksanaan penelitian ini pada semester genap Tahun Pelajaran 2012/2013, dengan senggang waktu 4 minggu yang dimulai minggu ketiga bulan April sampai minggu terakhir bulan Mei.

Subjek penelitian seluruh siswa kelas IV yang berjumlah 22 orang anak, terdiri dari 12 orang laki-laki dan 10 orang perempuan dengan usia rata-rata 9-10 Tahun dan memliki kemampuan bervariasi dan karakteristik yang berbeda. Setiap anak berasal dari latar belakang ekonomi yang berbeda, dimana orang tua anak didik ada yang berprofesi sebagai petani, buruh harian, pembawa bentor, pedagang dan PNS.

Prosedur penelitian ini dilaksanakan dalam bentuk siklus yang melalui empat tahap yaitu tahap persiapan, tahap pelaksanaan tahap pemantauan dan evaluasi dan tahap analisis dan refleksi.

Teknik analisi data dilakukan secara bertahap dan berkesinambungan pada setiap akhir siklus pembelajaran. Data yang dianalisi meliputi data hasil pengamatan kegiatan siswa dalam menyusun kembali isi pantun anak dengan teknik skrambel.

\section{HASIL DAN PEMBAHASAN}

Penelitian tindakan kelas ini dilaksanakan dalam dua siklus. Peneliti sebelum melaksanakan tindakan telah melakukan observasi awal sebagai langkah awal dalam pengambilan data permasalahan kemampuan siswa dalam menyusun kembali isi pantun, dari hasil observasi tersebut, ditemukan bahwa sebagian besar siswa belum bisa menyusun kembali isi pantun anak sesuai dengan kriteria penilaian ketekunan maupun keberanian saat menyusun pantun anak pada materi yang disajikan oleh guru.

Dari pelaksanaan kegiatan belajar mengajar pada observasi awal yang dilakukan oleh guru mitra dengan menggunakan lembar pengamatan kegiatan siswa saat menyusun pantun diperoleh hasil ang sangat rendah, yakni dari 22 jumlah keseluruhan siswa hanya 5 orang siswa (23\%) yang memiliki kemampuan menyusun pantun di atas kriteria ketuntasan minimal (KKM) yang telah ditetapkan. Sebagaimana nampak pada lampiran 1 pada halaman 39

Dari hasil observasi kegiatan siswa yang dilakukan pada kegiatan observasi awal ini terlihat jelas kemampuan siswa dalam menyusun pantun anak di depan kelas masih sangat jauh dari harapan. Setelah diperoleh hasil observasi kegiatan tersebut maka peneliti dan guru mitra merumuskan untuk meningkatkan kemampuan siswa dalam menyususn pantun adalah dengan menggunakan teknik skrambel.

\section{Tahap Siklus I}

Setelah dilaksanakan kegiatan pembelajaran pada siklus $\mid$ dengan menggunakan teknik skrambel maka diperoleh hasil kegiatan pembelajaran siswa pada siklus I dapat dilihat dari tiga aspek yang diamati menunjukan peningkatan ketuntasan belajar dari kegiatan sebelumnya sehingganya dari hasil kegiatan pembelajaran pada siklus I ini dapat dianalisis hasil seperti pada tabel 1 
Tabel 1 : Hasil pengamatan kegiatan siswa pada siklus I dengan teknik skrambel

\begin{tabular}{|c|c|c|c|c|c|c|c|c|c|c|c|}
\hline \multirow[t]{2}{*}{ No } & \multirow[t]{2}{*}{ Nama Siswa } & \multicolumn{3}{|c|}{$\begin{array}{l}\text { Menyusun kalimat } \\
\text { padu }\end{array}$} & \multicolumn{3}{|c|}{$\begin{array}{c}\text { Menentukan } \\
\text { sampiran pantun }\end{array}$} & \multicolumn{3}{|c|}{$\begin{array}{l}\text { Menyusun kembali } \\
\text { isi pantun }\end{array}$} & Jlh \\
\hline & & 3 & 2 & 1 & 3 & 2 & 1 & 3 & 2 & 1 & 9 \\
\hline & Jumlah & 8 & 14 & & 7 & 15 & & 7 & 14 & 1 & \\
\hline & Persentase (\%) & 36 & 64 & & 32 & 68 & & 32 & 64 & 4 & \\
\hline
\end{tabular}

(\%) Ketuntasan

$73 \%$

Keterangan : $\quad 3=$ Mampu $\quad 2=$ Kurang Mampu $\quad 1=$ Tidak Mampu

Dari hasil analisis data pada kegiatan siklus I dengan menggunakan teknik skrambel dapat dijelaskan berikut ini:

a. Pada aspek kemampuan menyusun kalimat padu nampak terdapat 8 orang siswa atau $36 \%$ sesuai hasil pengamatan masuk pada kategori mampu (M) dan dari 22 jumlah siswa keseluruhan nampak 14 orang siswa atau $64 \%$ pada kategori kurang mampu (KM) dan pada aspek ini tidak terdapat siswa yang tidak mampu (TM) menyusun kalimat pantun yang padu

b. Pada aspek kemampuan menentukan sampiran pantun sesuai hasil pengamatan dan analisis terdapat 7 orang siswa atau $32 \%$ yang telah mampu (M) menentukan sampiran pantun dengan baik, dan 15 atau $68 \%$ siswa masuk pada kategori kurang mampu (KM) dan pada aspek ini tidak terdapat siswa tidak mampu dalam menentukan sampiran pantun.

c. Pada aspek kemampuan menyusun kembali isi pantun dari 22 jumlah siswa nampak hanya terdapat 7 orang siswa atau $32 \%$ yang telah berhasil masuk pada kategori mampu (M), dan 14 orang siswa atau $64 \%$ masuk pada kategori kurang mampu (KM) sedangkan untuk kategori tidak mampu (TM) terdapat 1 orang atau 4 $\%$ belum mampu menyusun kembali isi pantun.
Dari hasil analisis data yang diperoleh pada kegiatan pembelajaran di siklus I dari ketiga aspek yang diamati jika di rata-ratakan yang telah mampu menyusun kembali isi pantun anak jika di persentasikan baru sekitaran $33 \%$. Dan ketuntasan belajar dari 22 jumlah siswa yang dikenai tindakan baru mencapai $73 \%$. Jika di bandingkan pada kegiatan observasi awal siswa yang telah berhasil sesuai hasil capain siswa jika dipersantasikan $23 \%$. Jadi pelaksanaan kegiatan pembelajaran pada siklus I ini nampak telah terjadi peningkatan ketuntasan belajar sebesar $50 \%$.

Format pengamatan kegiatan guru dalam proses pembelajaran mencakup 24 aspek dari pra pembelajaran sampai dengan menutu pembelajaran. Berdasrakan hasil pengamatan yang dilakukan oleh guru mitra terhadap peneliti dengan memperhatikan data hasil kegiatan guru dalam proses pembelajaran sebagimana nampak pada lampiran 1c Halaman 44 telah menunjukan bahwa pengelaolan yang dilakukan peneliti belum memenuhi target yang diharapkan dengan mendominasinya guru tidak melaksanakan kegiatan sesuia dengan aspek yang diamati dengan persentase $67 \%$.

Dengan demikian sesuia hasil analisis data pada pelaksanaan kegiatan siklus I ini, dapat diambil kesimpulan bahwa kegiatan siklus I ini telah terjadi peningkatan khususnya 
pada kemampuan siswa dalam menyusun kembali isi pantun dimana pada hasil capain siswa pada observasi awal ketuntasan belajar hanya $23 \%$, setelah ditindaki dengan menggunakan teknik skrambel telah terjadi peningkatan sebesar $50 \%$, dimana pada kegaiatan siklus I ini ketuntasan belajar telah mencapai $73 \%$. Sedangkan pada aspek pengamatan kegiatan guru dalam proses pembelajaran nampak masih mendomiasinya guru tidak melaksanakan prosedur yang menjadi aspek penilaian dari ke 24 aspek yang diamati dengan persentase $67 \%$. Namun dengan melihat hasil capain siswa atau ketuntasan belajar belum mencapai target inidikator kinerja yang telah ditetapkan dalam penelitian ini maka peneliti dan guru mitra menyimpulkan untuk diadakannya tindakan perbaikan pada siklus II sebagai bentuk penyempuraan dari pada siklus sebelumnya (siklus I).

\section{Tahap Siklus II}

Pada kegiatan pelaksanaan tindakan siklsu II merupakan tindak lanjut dari siklus I, dalam hal ini kekurangan pada siklus I diperbaiki pada tindakan siklus II serta diupayakan untuk dapat memecahkan masalah yang telah ditemukan oleh peneliti maupun guru pengamat selama proses pembelajaran.

Pada tahap ini peniliti kembali Mempersiapkan administrasi pembelajaran berupa menyusun instrumen pemantau kegiatan siswa yang diamati dari ketiga aspek, serta Menyusun skenario pembelajaran. Dari pelaksanaan tindakan pada siklus II yang dilaksanakan pada minggu yang sama sesuai prosedur pelaksanaan tindakan pada siklus sebelumnya (siklus I) dalam peningkatan kemampuan siswa menyusun kembali isi pantun melalui teknik skrambel. berikut:

Dengan langkah-langkah sebagai

a. Guru menyampaikan apersepsi sesuai dengan indikator pembelajaran

b. Guru kembali menyiapkan kelas dalam hal ini pembegaian kelompok belajar siswa.

c. Guru menyiapkan sebuah pantun anak, kemudian keluarkan kata-kata yang terdapat dalam isi pantun anak kedalam kartu-kartu kata.

d. Guru membuat kartu soal beserta jawabannya sesuai dengan pantun yang telah dibagikan sebelumnya dan membagikan kartu soal tersebut.

e. Siswa dalam kelompok masing-masing mengerjakan soal dan mencari kartu soal untuk jawaban yang cocok, sebelumnya jawaban telah diacak sedemikian rupa.

f. Siswa diharuskan dapat menyusun kata jawaban yang telah tersedia dalam waktu yang telah ditentukan. Setelah selesai mengerjakan soal, hasil pekerjaan siswa dikumpulkan untuk dilakukan pemeriksaan.

g. Guru dan siswa memberikan kesimpulan materi

Setelah dilaksanakan kegiatan pembelajaran pada siklus II dengan teknik skrambel maka diperoleh hasil pelaksanaan kegiatan siswa pada siklus II ini nampak telah terjadi peningkatan pada ketiga aspek yang diamati. Dari hasil pengamatan ini jika dianalisis data kemampuan siswa dalam menyusun kembali isi pantun melalui teknik skrambel sebagimana terlihat pada tabel 2

Tabel 2 : Hasil Analisis data kegiatan siswa pada siklus II dengan menggunakan teknik skrambel 


\begin{tabular}{|c|c|c|c|c|c|c|c|c|c|c|}
\hline \multirow[t]{2}{*}{ No } & \multirow[t]{2}{*}{ Nama Siswa } & \multicolumn{3}{|c|}{$\begin{array}{l}\text { Menyusun kalimat } \\
\text { padu }\end{array}$} & \multicolumn{3}{|c|}{$\begin{array}{c}\text { Menentukan } \\
\text { sampiran pantun }\end{array}$} & \multicolumn{3}{|c|}{$\begin{array}{l}\text { Menyusun kembali } \\
\text { isi pantun }\end{array}$} \\
\hline & & 3 & 2 & 1 & 3 & 2 & 1 & 3 & 2 & 1 \\
\hline & Jumlah & 12 & 10 & & 13 & 9 & & 17 & 5 & \\
\hline & Persentase (\%) & 55 & 45 & & 59 & 41 & & 77 & 23 & \\
\hline & $(\%)$ Ketuntasan & \multicolumn{9}{|c|}{$95 \%$} \\
\hline
\end{tabular}

Keterangan : $\quad 3=$ Mampu $\quad 2=$ Kurang Mampu $\quad 1=$ Tidak Mampu

Dari hasil analisis data pada kegiatan pembelajaran pada siklus II dengan menggunakan teknik skrambel dalam menyusun isi pantun dapat dijelaskan sebagai berikut:

a. Sesuai hasil pengamatan khususnya pada aspek kemampuan menyusun kalimat padu dari 22 jumlah keseluruhan siswa yang dikenai tindakkan nampak telah mondominasi dengan terdapat 12 siswa atau $55 \%$ telah mampu menyusun kalimat yang padu dengan kategori mampu (M) dan untuk kategori kurang mampu (KM) terdapat 10 orang siswa atau $45 \%$ dari jumlah keseluruha siswa yang dikenai tindakan, dan pada tindakan siklus II ini pada aspek ini tidak terdapat siswa yang masuk pada kategori tidak mampu (TM). sehingganya jika disimpulkan pada aspek kemampuan menyusun kalimat padu ini siswa yang telah mampu.

b. Pada aspek Kemampuan menentukan sampiran pantun juga telah terjadi peningkatan dari siklus Sebelumnya dimana pada siklus I untuk kategori mampu hanya 7 orang siswa atau $32 \%$ dan pada siklus II ini terjadi peningkatan dengan 13 orang siswa atau $59 \%$ siswa yang masuk pada kategori mampu (M). Untuk kategori yang tidak mampu (TM) pada aspek ini sesuai hasil pengamatan tidak ada

c. Aspek kemampuan menyusun kembali

isi pantun telah terjadi peningkatan terhadap peneliti telah melampaui jauh dari indikator kinerja yang telah ditetapkan pada penelitian ini dinilai telah berhasil dan tidak perlu lagi dilanjutkan pada siklsu selanjutnya. Berdasarkan hasil penelitian di atas jelaslah bahwa teknik skrambel merupakan salah satu pendekatan yang dapat menunjang proses bahkan hasil pembelajaran di sekolah dasar. sebagaimana yang nampak pada tabel analisis diatas dengan terdapatnya 17 orang siswa atau $77 \%$ yang telah mampu (M) menyususn kembali isi pantun anak dengan baik dan benar.

Dari hasil analisis data dari siklus I sampai pada perbaikan siklus II telah terjadi peningktan sebesar $22 \%$. Berdasarkan pengamatan yang dilakukan oleh guru mitra terhadap peneliti dengan memperhatikan data hasil kegiatan belajar pada siklsu II sebagaimana nampak pada lampiran 2c halaman 49 telah menunjukan bahwa pengelolan yang dilakukan oleh peneliti sudah memenuhi target yang diharapkan, diaman dari 24 aspek nampak telah mendominasi guru sudah melakukan aspek-spek yang diamati dengan $96 \%$.

Setelah melaksanakan kegiatan pembelajaran pada siklus II, dalam hal ini sebagai bentuk penyempurnaan dari pelaksanan tindakan pada siklus sebelumnya, dengan tujuan meningkatkan kemampuan siswa dalam menyusun kembali isi pantun anak yang diamati dari tiga aspek dengan menggunakan teknik skrambel pada siswa kelas IV, Setelah dilaksanakan pelaksanaan tindakan pada siklus II, maka peneliti dan guru mitra mengadakan kegiatan refleksi. Berdasarkan hasil refleksi, bahwa setelah melihat hasil capaian kemampuan siswa pada proses pembelajaran maupun hasil pengamatan yang dilakukan oleh guru mitra Kondisi ini mengingat bahwa penggunaan teknik skrambel ini sangat membantu siswa dalam memahami konsep-konsep dalam menyusun isi pantun anak sesuai dengan harapan, sejalan dengan itu pelaksanaan interaksi belajar mengajar yang menitik beratkan pada peningkatan kemampuan siswa dalam menyusun kembali isi pantun pada siswa 
kelas IV SD 4 Telaga Jaya Kabupaten Gorontalo sebagaimana telah dikemukakan pada bab-bab terdahulu adalah untuk mencapai indikator kinerja keberhasilan adalah untuk hasil capaian siswa minimal $75 \%$ dari seluruh siswa yang dikenai tindakan di tunjukan oleh hasil capain siswa rata-rata memperoleh nilai minimal 70 keatas.

Segala sesuatu yang dilakukan dalam proses pembelajaran adalah selalu berupaya meningkatkan kualitas dan hasil capain siswa yang memuaskan, untuk mencapai hal tersebut tentunya siswa harus termotivasi dan berperan aktif dalam kegiatan proses pembelajaran agar siswa selalu merasa senang pada setiap kegiatan pembelajaran yang diajarkan oleh guru.

Data yang diperoleh melalui pelaksanaan tindakan siklus I pada peningkatan kemampuan siswa dalam menyusun pantun pada kegiatan siswa dari ketiga aspek yang diamati khususnya pada aspek kemampuan menyusun kalimat padu nampak 8 orang siswa atau sekitar $36 \%$ yang masuk pada kategori mampu (M) dan untuk aspek kemampuan menentukan sampiran pantun nampak 7 orang siswa atau $32 \%$ dari 22 orang jumlah keseluruhan telah berhasil masuk pada kategori mampu (M), sedangkan untuk aspek kemampuan menyusun kembali isi pantun nampak 7 orang siswa atau $32 \%$ yang telah mampu sedangkan hasil pengamatan kegiatan guru dalam proses pembelajaran nampak masih mendominasinya kualifikasi guru tidak melakukan sesuai dengan indikator aspek yang diamati dengan $67 \%$.

Jika dirata-ratakan dari ketiga aspek yang telah berhasil dengan kategori mampu sekitar $33 \%$, dengan ketuntasan hasil belajar siswa pada siklus ini sebesar $73 \%$ maka hal ini telah menunjukan peningkatan kemampuan siswa dalam menyusun kembali isi pantun dari kegiatan observasi awal akan tetapi hasil capain ketuntasan belajar siswa pada kegiatan siklus I ini belum mencapai standar indikator ketuntasan belajar yang telah di tetapkan pada penelitian ini untuk itu sesuai dengan hasil refleksi maka tindakan dalam penelitian harus dilanjutkan pada siklus II hal ini dilakukan adalah sebagai bentuk penyempurnaan dari kegiatan sebelumnya (siklus I).

Dari hasil perbaikan langkah-langkah pembelajaran tersebut, maka telah terjadi peningkatan kualitas pembelajaran pada siklus II dalam proses pembelajaran yang diamati dari ketiga aspek sebagaiman dijelaskan berikut ini: khusus pada aspek kemampuan menyusun kalimat padu nampak telah mendominasinya dengan $55 \%$ untuk kategori mampu, sedangkan pada aspek kemampuan menentukan sampiran pantun nampak telah terjadi peningkatan dengan 59 \% siswa yang masuk pada kategiri mampu (M), dan pada aspek kemampuan menyusun kembali isi pantun juga telah mendominasi oleh siswa yang masuk pada kategori mampu (M) dengan $77 \%$. Dengan ketuntasan belajar pada siklus II ini telah mencapai $95 \%$. Sedangkan untuk hasil pengamatan kegiatan guru pada siklsu liini dari 24 aspek yang diamati nampak telah mendominasinya kulifikasi guru telah melakukan sesuai dengan indikatir/aspek yang diamati dengan $96 \%$.

Berdasarkan gambaran deskripsi data dan pembahasannya seperti di atas, jelaslah bahwa peningkatan kemampuan siswa dalam menyusun kembali isi pantun pada (siklus I) sampai dengan pelaksanaan tindakan dengan menerapkan langkah-langkah pembelajaran yang relevan dengan pengajaran tersebut (Siklus II) nampak sekali terjadi perubahan yang positif. Artinya bahwa teknik skrambel ini sangat cocok untuk disajikan pada siswa dalam meningkatkan kemampaun siswa dalam menyusun kembali pantun anak ternyata banyak membantu dalam memotivasi siswa untuk belajar, artinya setiap siswa dapat mengadakan asosiasi atau kolaborasi antara materi yang diperolehnya dengan teman sekelasnya 


\section{KESIMPULAN dan SARAN \\ Kesimpulan}

Beberapa simpulan dalam penelitian ini sebagai berikut:

1)Penggunaan teknik skrambel ternyata dapat meningkatkan kemampuan menyusun kembali isi pantun pada siswa kelas IV SDN 4 Telaga Jaya Kabupaten Gorontalo, yakni dari $23 \%$ ketuntasan belajar pada kegiatan observasi awal, dengan menggunakan metode ceramah, meningkat menjadi $73 \%$ pada kegiatan siklus I dengan menggunakan teknik skrambel dengan tiga aspek yang diiamati, dari hasil kegiatan siklsu I di refleksi dan disimpulkan untuk diadakannya tindakan perbaikan pada siklsu II memperoleh hasil peningkatan kemampuan siswa dalam menyusun kembali isi pantun hingga mencapai $95 \%$ ketuntasan belajar.

2)Dengan menggunakan teknik skrambel kemampuan menulis kembali isi pantun anak pada siswa kelas IV SDN 4 Telaga Jaya Kabupaten Gorontalo meningkat.

\section{Saran}

Adapun saran-saran dari hasil penelitian sebagai berikut:

1. Dalam kegiatan proses pembelajaran kiranya siswa lebih diberikan kesempatan untuk mengeksplorasikan pendapat dan juga kreativitas yang dimiliki agar siswa lebih termotivasi dalam mengapresiasikan potensi yang dimilikinya.

2. Guru dalam meningkatkan kualitas hasil belajar sesuai dengan harapan tentunya guru dapat memilih strategi pengajaran yang sesuai dengan materi dan karakteristik siswa.

3. Sekolah agar kiranya pihak sekolah memfasilitasi setiap pembelajaran yang tujuannya memajukan kualitas pendidikan agar menghasilkan output yang mempunyai perspektif juga keterampilan pada diri siswa

4. Peneliti dengan pelaksanaan kegiatan tindakan kelas ini menjadi suatu acuan untuk peningkatan kualitas pendidikan khususnya di Gorontalo
DAFTAR PUSTAKA

Dramadi Kaswan, dkk. 2008. Bahasa Indonesia 4 BSE. Jakarta: Pusat Perbukuan, Departeme Pendidikan Nasional

Depdikbud. 2007. Pedoman Pelaksanaan Kurikulum Tingkat Satuan Pendidikan. Tentang Pengolahan Analisis dan Pelaporan Kemampuan. Jakarta

Khamdanah, Eris.2005. Meningkatkan kemampuan menulis pantun anak terhadap siswa kelas IV SDN 1 Kertek Kabupaten Wonosobo Universitas Negeri Semarang.

Panghulu, 2008. Pembelajaran Apresiasi Sastra. Jakarta: Rosda Karya

Soetarno, 2008. Peristiwa Sastra Melayu Lama. Surakarta: Widya Duta Grafika

Somadayo, Samsu. 2011 Strategi Dan Teknik Pembelajaran Membaca. Yogyakarta : Graha llmu.

Sumiyadi, dkk. 2009. Kesussastraam Modul suplemen kegiatan pelatihan di KKG pada program bermutu. Jakarta: DIRJEN

Sulistiawati, Winda. 2011. Peningkatan kemampuan membuat pantun dengan teknik Skrambel pada siswa kelas IV SDN Tanjung Rejo2 Malang.Universitas Negeri Malang.

Supriyadi. 2006. Pembelajaran Sastra Yang Apresiatif dan Integratif di Sekolah Dasar. Jakarta: DIRJEN

Tugino 2010. Media Belajar Bahasa. Yogyakarta: Graha IImu

Wardani, dkk. 2006. Penelitian tindakan kelas. Jakarta :Universitas Terbuka.

Widiyati, Indriani. 2005. Skripsi peningkatan keterampilan membaca pemahaman dengan teknik skrambel. Universitas Negeri Semarang.

Wiraguna, Aryo. 2012. Meningkatkan hasil belajar siswa kelas IV menyusun pantun dengan teknik komunikatif Sekolah Dasar Negeri Umbulwidodo Ngemplak Sleman. Universitas Negeri Yogyakarta.

Zulela.2012 Apresiasia sastra anak SD. Jakarta: Rosda Karya: 